\title{
Tree ring growth as a response of silver fir (Abies alba Mill.) from Rudnik Forest District to climatic factors
}

\author{
Monika Tomczyk-Kida ${ }^{1} \bowtie$, Grzegorz B. Durło², Sławomir Wilczyński ${ }^{2}$ \\ ${ }^{1}$ Forest Research Institute, Department of Mountain Forests, Fredry 39, 30-605 Kraków, Poland, \\ e-mail: M.Tomczyk-Kida@ibles.waw.pl \\ ${ }^{2}$ University of Agriculture in Kraków, Faculty of Forestry, Departament of Forest Protection, \\ Entomology and Forest Climatology, al. 29 Listopada 46, 31-425 Kraków, Poland
}

\begin{abstract}
The aim of the study was to evaluate the sensitivity of silver fir (Abies alba Mill.) from the Rudnik Forest District on the selected meteorological elements and to develop a chronology of local tree-ring width and the annual sensitivity.

Based on the analysis, the site chronology of silver fir was developed and the strength of the relationship between the climate components and the width of annual rings was calculated. In addition, we examined the degree of homogeneity of short-term incremental response, rated the representativeness of the chronology and climate signal strength.

Having analysed the indicator years, namely 1932-2013, we concluded that the growth of firs was positively influenced mainly by air temperature in winter, and to a lesser extent, by precipitation in spring and summer. The main factors that limit its growth are cold winters, cool and low rainfall summers, and rainy springs.
\end{abstract}

\section{KeY WORDS}

Abies alba, climate, dendrochronology, dendroclimatology, dendrochronological analysis

\section{INTRODUCTION}

Silver fir (Abies alba Mill.), as the only species of the genus Abies occurring naturally in Poland, has always aroused special interest of arboriculturists and foresters. In Poland, it can be found mainly in the Carpathians, the Świętokrzyskie Mountains and the Sudeten Mountains. Covering about $3.2 \%$ of the total forest area (BDL 2017), it is an important forest-building species of the lower forest zone for economic reasons and it has protective qualities (Tomanek 1996). The fir reaches the northern limit of its range in Poland (Bronisz et al. 2010).

At the turn of the 1960s and 1970s, the decline of fir was observed in Poland. During this time, the growth in fir had reduced or disappeared, which is attributed to a combination of adverse climatic conditions and atmospheric pollution. Zawada (1978, 1987, 2001), Ukleja-Dobrowolska (1989) and Szymura (2008) believed that it was mainly the increase in emission 
of pollutants that contributed to the phenomenon described above. Historically, the decline of this species was observed most strongly in the Sudeten Mountains, Świętokrzyskie Mountains and the Silesian Upland (Sugiero 2005). After two decades of regression, fir regained its vitality and, in many regions, it is recovering to its positive growth patterns and its potential is steadily increasing.

The analysis of annual growth of trees is one of the methods used to diagnose the habitat conditions and serves as the basis for evaluation of the habitat potential. In addition, these methods allow the assessment of the trees' sensitivity to changes in environmental conditions in the long run (Zielski and Krąpiec 2009; Bijak 2013). So far, dendrochronological studies on fir have been undertaken relatively rarely. In Poland, they were conducted mainly by Feliksik (1990), Wilczyński (2010, 2013) and Wilczyński and Wertz (2012). They show that the factors limiting the growth of fir in recent decades were long and very cold winter and precipitation deficiency in the summer period. There are suggestions that growth sensitivity of silver fir to summer droughts decreases when growing in mixed stands (Lebourgeois et al. 2013). Carrer et al. (2010) showed a strong correlation between precipitation and radial growth in different Mediterranean forests. Lebourgeois et al. (2014) showed that growth of Abies is being driven mainly by previous and current late summer temperatures.

The aim of this study was to analyse the effect of selected meteorological elements such as precipitation and air temperature on the dynamics of fir thickness increase in the Rudnik Forest District.

\section{Material AND MEthods}

\section{Characteristics of the area under study}

The research material was collected in the Rudnik Forest District (160-200 m above sea level) (Fig. 1), more specifically in the Zalesie Forestry Unit, which belongs to the Regional Directorate of State Forests in Lublin. The geographical coordinates of the Rudnik Forest District territory's extreme points are as follows: in the north $50^{\circ} 31^{\prime} 40^{\prime \prime} \mathrm{N}, 22^{\circ} 9^{\prime} 45^{\prime \prime} \mathrm{E}$; in the south $50^{\circ} 19^{\prime} 40^{\prime \prime}$ $\mathrm{N}, 22^{\circ} 2^{\prime} 45^{\prime \prime} \mathrm{E}$; in the east $50^{\circ} 29^{\prime} 00^{\prime \prime N}, 22^{\circ} 24^{\prime} 25^{\prime}$ " E; in the west $50^{\circ} 21^{\prime} 00^{\prime \prime} \mathrm{N}, 22^{\circ} 27^{\prime} 20^{\prime \prime} \mathrm{E}$. According to the physical and geographical regionalisation of Poland, the area under study belongs to: the Region of Western Carpathians together with the Western and Northern Carpathian Foothills (Podkarpacie), Subregion of Northern Carpathian Foothills, macro-region of the Sandomierz Basin. The Rudnik Forest District was located in the

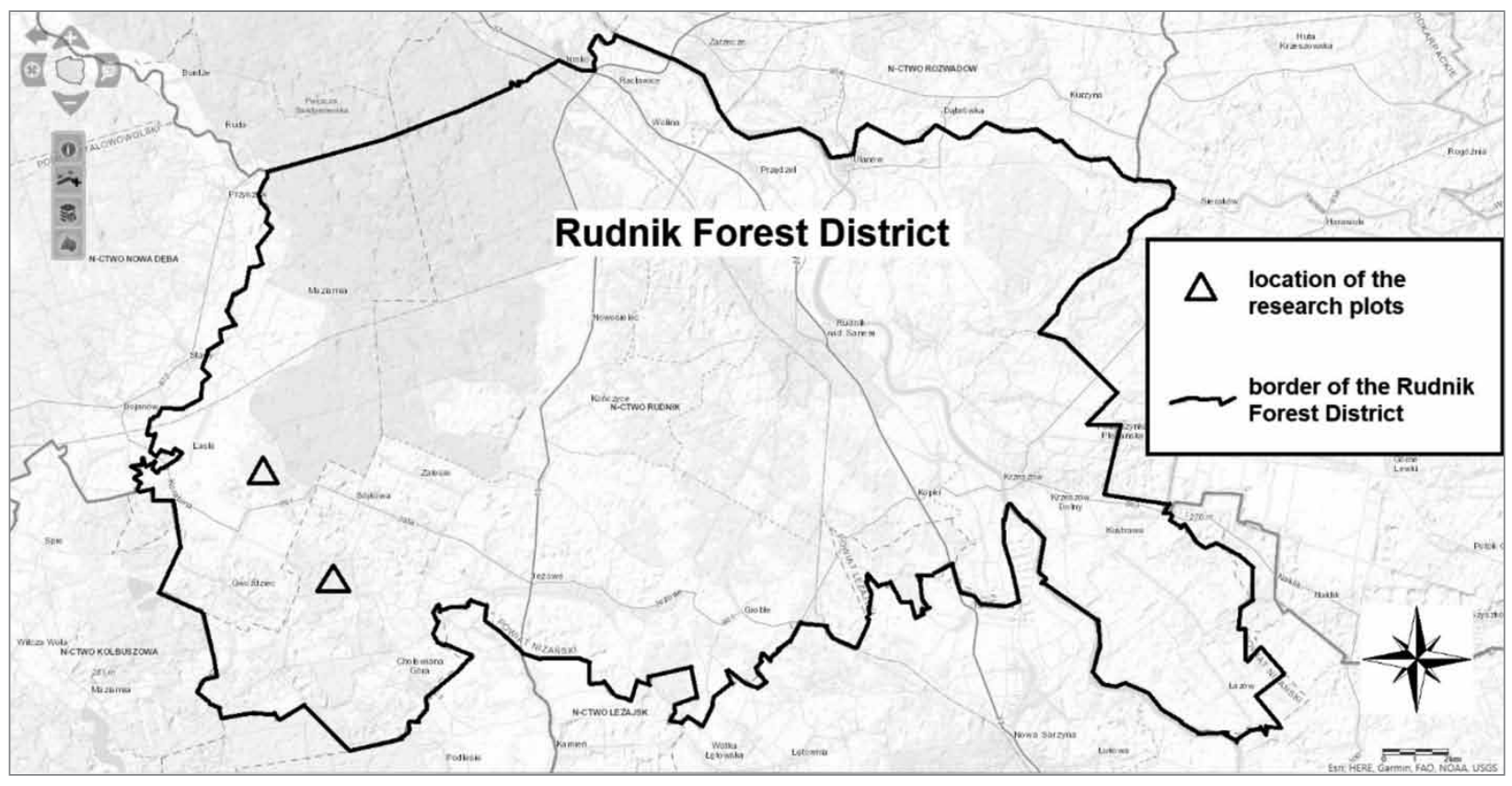

Figure 1. The range of the Rudnik Forest District with location of the research plots (source: BDL 2017) 
following mesoregions, Tarnobrzeg Plains, Lower San Valley, Kolbuszowa Plateau, Tarnogród Plateau (Kondracki 2011).

\section{Climate}

The climate of the area under analysis is transitional and continental. The weather in this area is shaped by the masses of polar-maritime air occurring mainly in summer and winter, as well as polar-continental air seen most often in spring and autumn. The average annual air temperature is $7.5^{\circ} \mathrm{C}$. July was the warmest month of the year with an average temperature of $18.5^{\circ} \mathrm{C}$. The coldest month is January with an average of $-3.3^{\circ} \mathrm{C}$ (Fig. 2). The most rainy month of the year is July (Fig. 2). The average winter lasts 80 -days and the snow cover lasts on average 72 days. Wind blowing from the west and east is found predominant here. The average duration of the growing season is 225 days (PUL 2012).

To carry out the dendrochronological analysis, climatic data from the weather station of the Institute of Meteorology and Water Management (IMGW) in Rzeszów for the period 1932-2012 were used. IMGW station in Rzeszów is located at $40 \mathrm{~km}$ from our sampling sites.

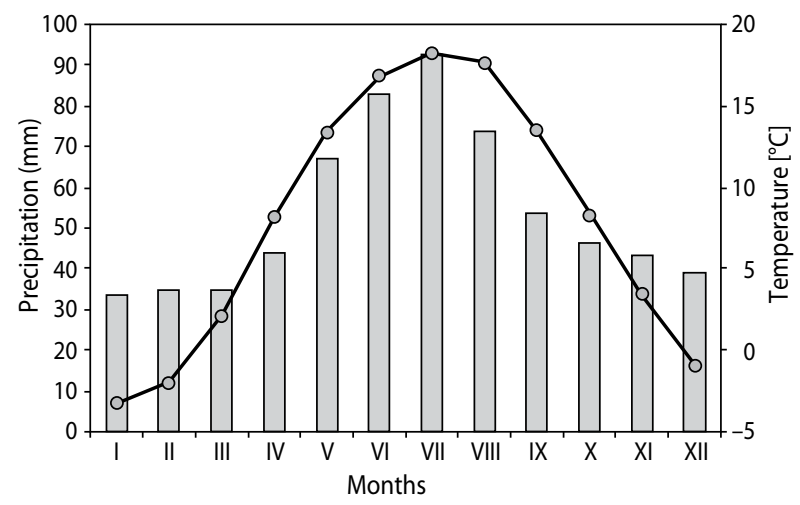

Figure 2. The variation of the average monthly air temperature (line) and average monthly precipitation (bars) for the meteorological station in Rzeszów for the period 1932-2012 (source: IMGW in Rzeszów)

\section{Study material and measurements}

The material for the analysis was collected in August 2013. The wood cores were taken at a height of $1.3 \mathrm{~m}$ above the ground, with the Pressler borer, from 25 silver fir trees in the Zalesie Forestry Unit (forest compart- ments 302 and 309) at an altitude of 190-200 m above sea level. The selected specimens, aged about 130 years old, had properly developed tree crowns, no symptoms of disease. The trees belonged to the first and second biosocial Kraft's class. Then, the width of the annual rings was measured with an accuracy of $0.01 \mathrm{~mm}$, using the BEPD-3 electromechanical increment gauge in the Department of Forest Protection, Entomology and Climatology University of Agriculture (ZOLEiKL UR) laboratory in Kraków, The correctness of ring agedating was verified using the COFECHA computer program (Holmes 1986). The measurements enabled to obtain a series of annual growth widths for each tree. The next step was to develop a series relating to the sensitivity and chronology from the ring width data. The rings width values from each site's chronology were transformed into the incremental index (annual sensitivity), thanks to which the effect of medium- and longterm variability was reduced (Fritts 1976). On the other hand, the short-term variability of the tree growth was emphasized, mainly related to the climatic factor. The annual sensitivity $C_{i}$ was calculated with the formula below:

$$
C_{i}=2\left(x_{i}-x_{i-1}\right)\left(x_{i}+x_{i-1}\right)^{-1}
$$

where:

$x_{i}$ - the ring width in the year $i$;

$x_{i-1}$ - ring width in the year preceding the year $i$ (Fritts 1976).

To assess the degree of uniformity of incremental responses of trees, the mean coefficient of series correlation, $r_{\text {mean }}$, was used (Wilczyński and Wertz 2012). Moreover, the EPS (Expressed Population Signal) was calculated, to test how well the studied series represents the given population of trees in the description of variability of their incremental response (Wigley et al. 1984). In order to determine the strength of the high-frequency signal (short-term variability) in relation to long-term variability, the SNR (Signal-to-Noise Ratio) has been calculated. The relationships between the width of rings, air temperature and precipitation were determined by the convergence index method (GL) (Huber 1943; Eckstein and Bauch 1969). The years providing indicators were also analysed in the material under examination. The method proposed by Wilczyński (2010) was used, in which the value of annual sensitivity was reduced to 
$C_{i} \geq 0.25$ (positive years) and $\leq-0.25$ (negative years), which resulted in a higher number of indicative years. Signature years are those that exhibit particularly narrow or wide annual growth. The research hypotheses were tested with a probability at $p=0.05$. For the statistical data treatment, Statistica 10 (StatSoft. Inc. 2011) was used.

\section{Results}

Tree-ring width do vary over the years and have grown, inter alia, in the years: 1910-1929, 1952-1960 and 1992-2002 (Fig. 3, 4). There are also periods, where the variations of the size of rings are consistent year to year, which proves that short-term incremental responses of rings are very uniform. It can therefore be assumed that the climatic factor affects the entire tree population.

The beginning of the analysed period experienced a decrease in growth that lasted until 1892, then there was an insignificant increase, followed by a slight decrease. Around 1965, there was a strong increase in growth, which lasted until 1997. It was found that the population of the trees under study showed not only medium- and long-term variability, but also clear annual variability. After 2002, there was a decrease in growth (Fig. 4).

The values of annual sensitivity $C_{i}$ never reached 2 or -2 (Fig. 5). On this basis, it can be assumed that during the period considered, there are generally no de-

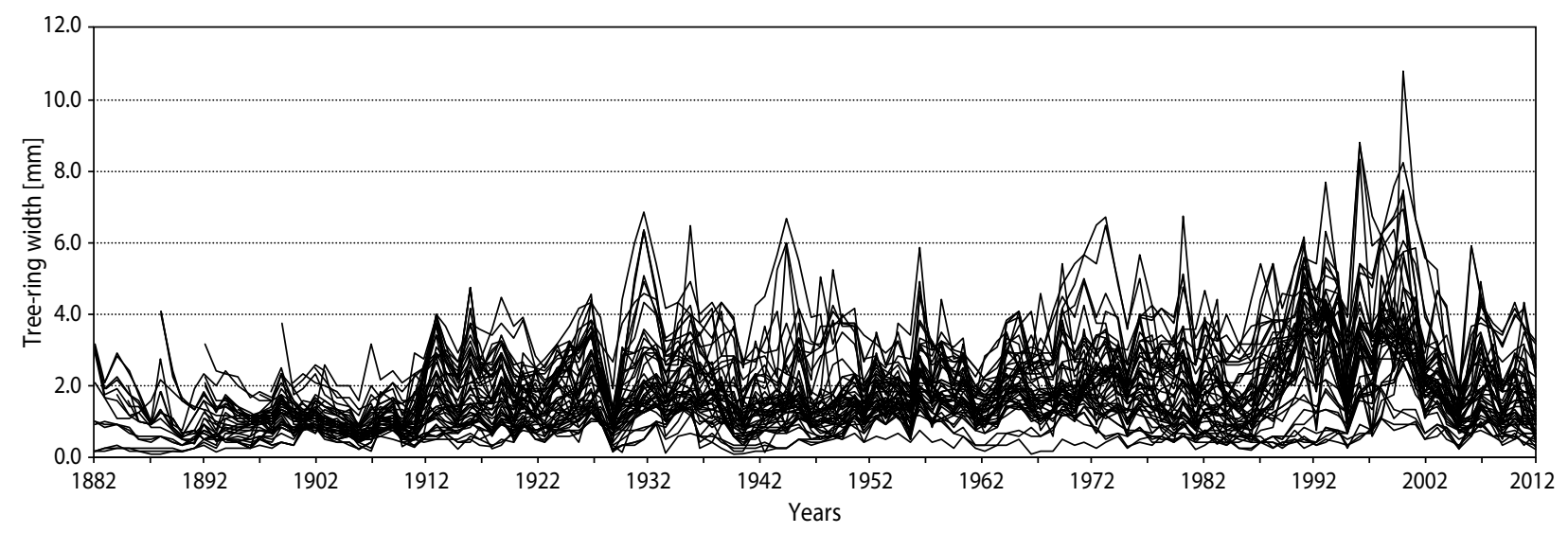

Figure 3. Individual sequences of tree-ring widths of 25 silver firs (Abies alba Mill.) from the Rudnik Forest District

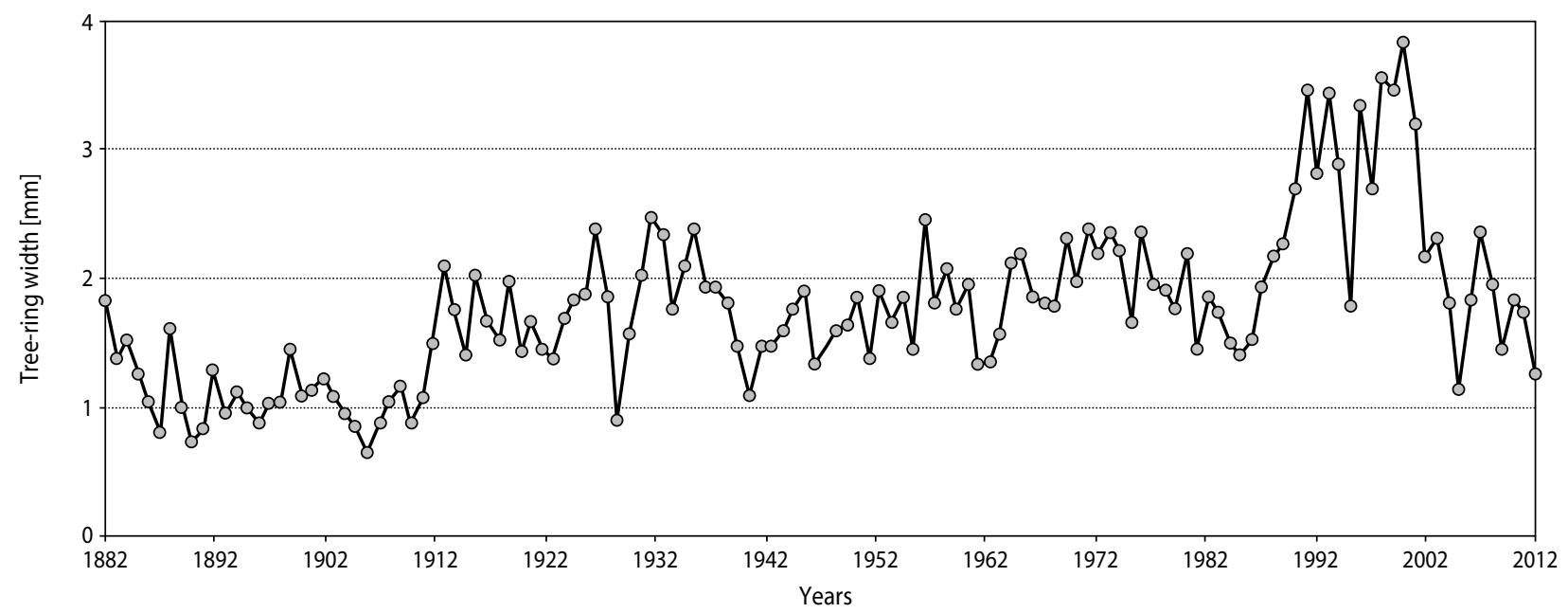

Figure 4. The site chronology of the tree-ring width of silver fir (Abies alba Mill.) from the Rudnik Forest District 


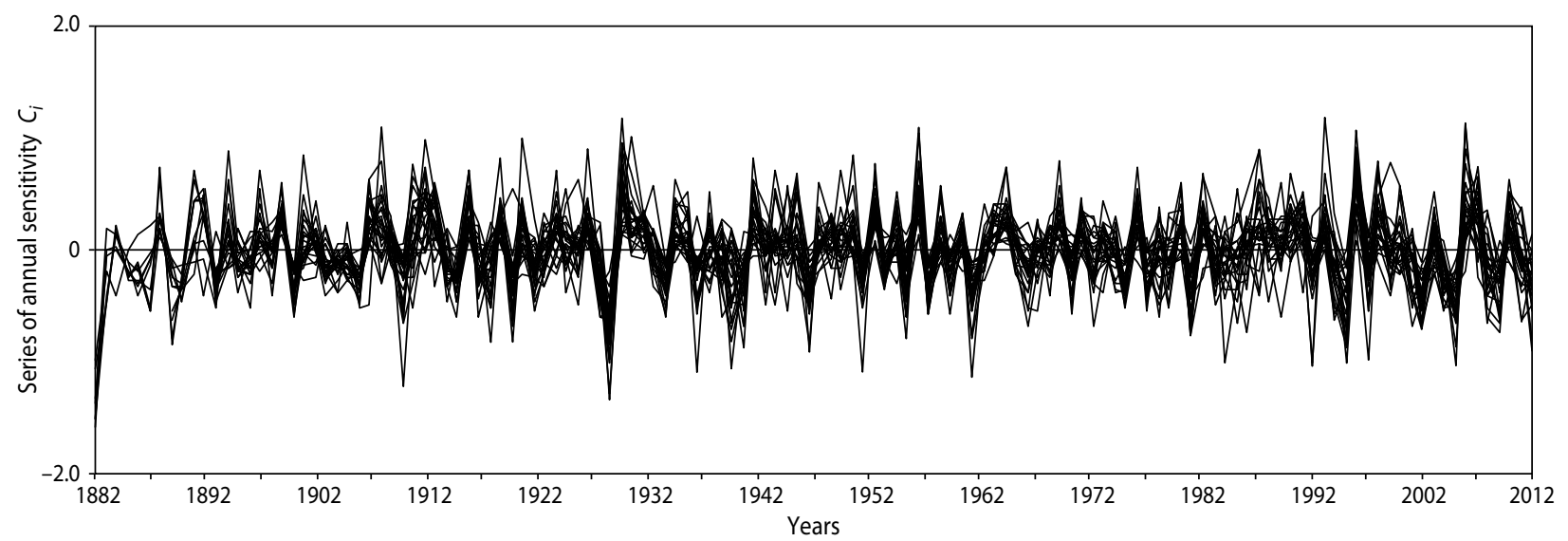

Figure 5. Series of annual $C_{i}$ sensitivity over the years on the examined areas from the Rudnik Forest District

cisive stimuli that would result in changes differentiating the width of fir rings. Rapid changes can be noted in 1909,1929 or 1957 (Fig. 5). In order to compare the variation of the ring width chronology with that of the sensitivity chronology, the convergence index was calculated to be $81 \%$. This means that variations of site chronologies are very similar to each other. It was found that there were years in which the vast majority of trees responded identically, but also years in which the series were less similar. In these years, there was a disturbance in the regular growth of certain trees, which could have been an effect of various non-climatic factors, such as sylvicultural treatments or damage caused by insect.

The correlation coefficient $r_{\text {mean }}$ of the sensitivity series was 0.58 , which proves that the trees being analysed were characterized by high short-term uniformity of incremental responses. Therefore, the EPS index of 0.95 for the period 1932-2012 indicates that the chronology developed in the presented study is highly representative. In turn, the SNR index was 18.2, which confirms that the climatic signal is very strong.

The analysis of the relationship between growth values and the climatic factors shows that a relatively warm winter and early spring of the current year, that is, January, February and March, had a positive and significant impact on the annual growth values (Fig. 6). In turn, the precipitation did not have such a large effect on the fir population considered. However, one case was observed where wet June had a positive effect on growth in trees. To sum up, the formation of annual growth rings was influenced to the greatest extent by the air temperature in winter higher than average for those months, the variability of temperature at the turn of winter and spring and precipitation at the beginning of summer.

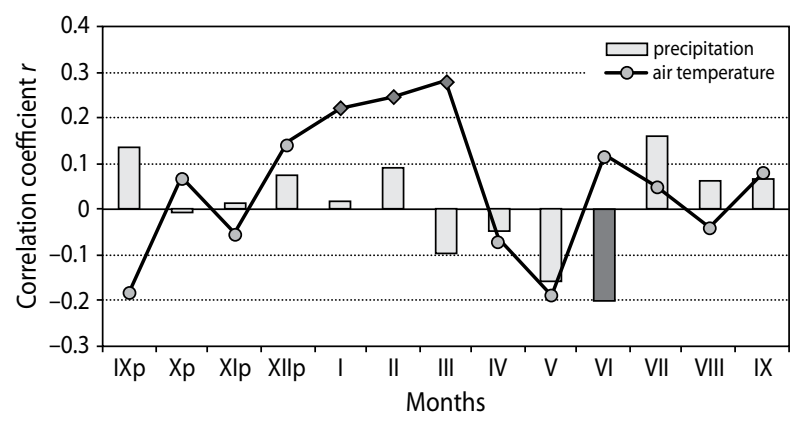

Figure 6. Correlation coefficient ' $r$ ' of site chronologies of fir sensitivity and monthly values calculated for air temperature and precipitation from September (IXp) of the previous year to September of the current year (IX). Significant values are marked in black, 'p' denotes the previous year

In the period 1882-2012, 21 indicator, negative years with a decrease in the ring width were highlighted (1889, 1893, 1900, 1906, 1910, 1915, 1920, 1929, 1934, 1941, 1947, 1952, 1956, 1958, 1962, 1976, 1982, 1996, $2003,2006,2010)$ as were 18 positive ones - showing an increase in the annual growth in comparison to the previous year $(1888,1892,1899,1907,1912,1913$, 1916, 1930, 1931, 1942, 1953, 1957, 1964, 1969, 1977, 1997, 1999, 2007) (Fig. 7). This indicates a stronger and uniform reaction of trees to the factors limiting their growth. In the considered population, indicator years appear relatively evenly. Situations were observed 
where positive indicator years occurred in a row, which was not found for the negative years. It is worth noting that the periods in which positive and negative indicator years occurred immediately in a row: 1888 - positive year, 1889 - negative year, 1892 - positive year, 1893 - negative year. From the climatic graphs, it can be concluded that positive years were conditional primarily upon high temperature in the winter period and early spring of the current year (January, February, March and April) and warm December of the previous year. The analysis of the correspondence between the site chronology of annual sensitivities and monthly mean values of temperature showed that March turned out to be the most important month (Fig. 8-10). The year 1956 was an example of a negative index year characterized by extremely low values of climate indices. It was then that the monthly average temperature of February, equal to $-13.1^{\circ} \mathrm{C}$, was the lowest in the entire period considered. The actual average growth in a given year compared to the previous years was much lower, that is, $1.44 \mathrm{~mm}$. In January, the lowest average monthly air temperature was $-12.4^{\circ} \mathrm{C}$, which was noted in 1963 , when the actual growth was $1.35 \mathrm{~mm}$. In March, however, the lowest average temperature was $-3.2^{\circ} \mathrm{C}$ in 1952 , while the actual growth at that time was $1.39 \mathrm{~mm}$. This is supported by the fact that not only very cold winter, but also very

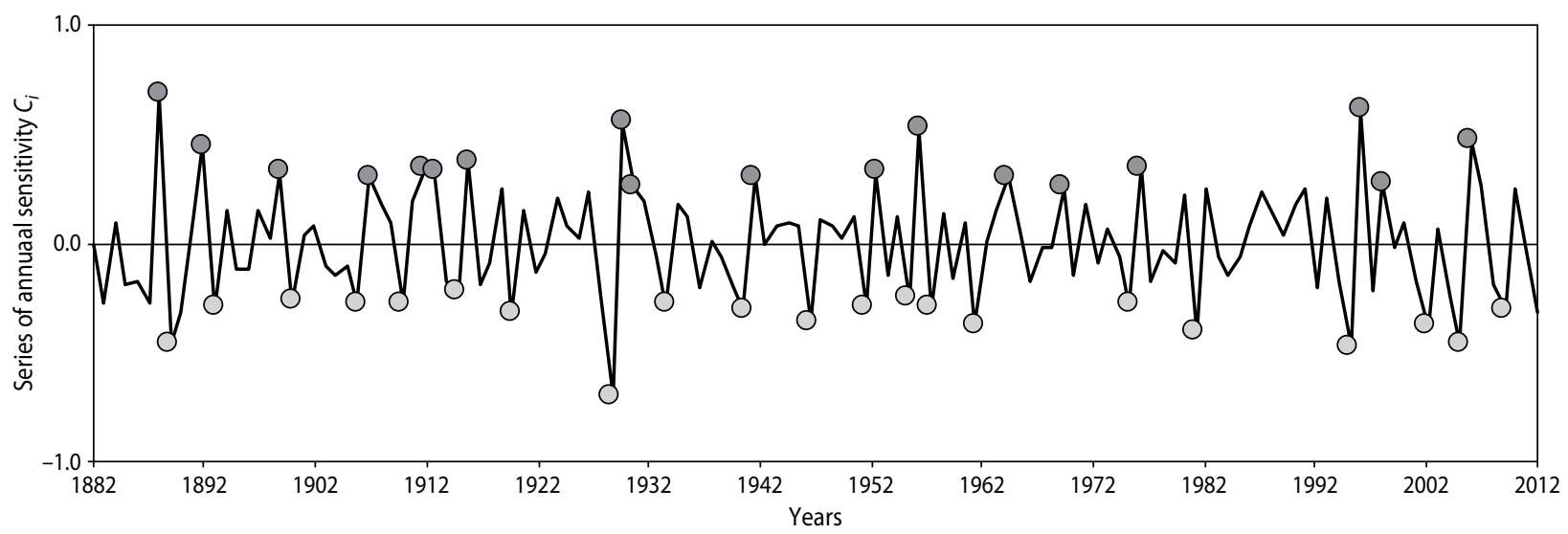

Figure 7. The site chronology of sensitivity of silver fir population (Abies alba Mill.) from the Rudnik Forest District and positive signature years (top points), negative signature years (bottom points)

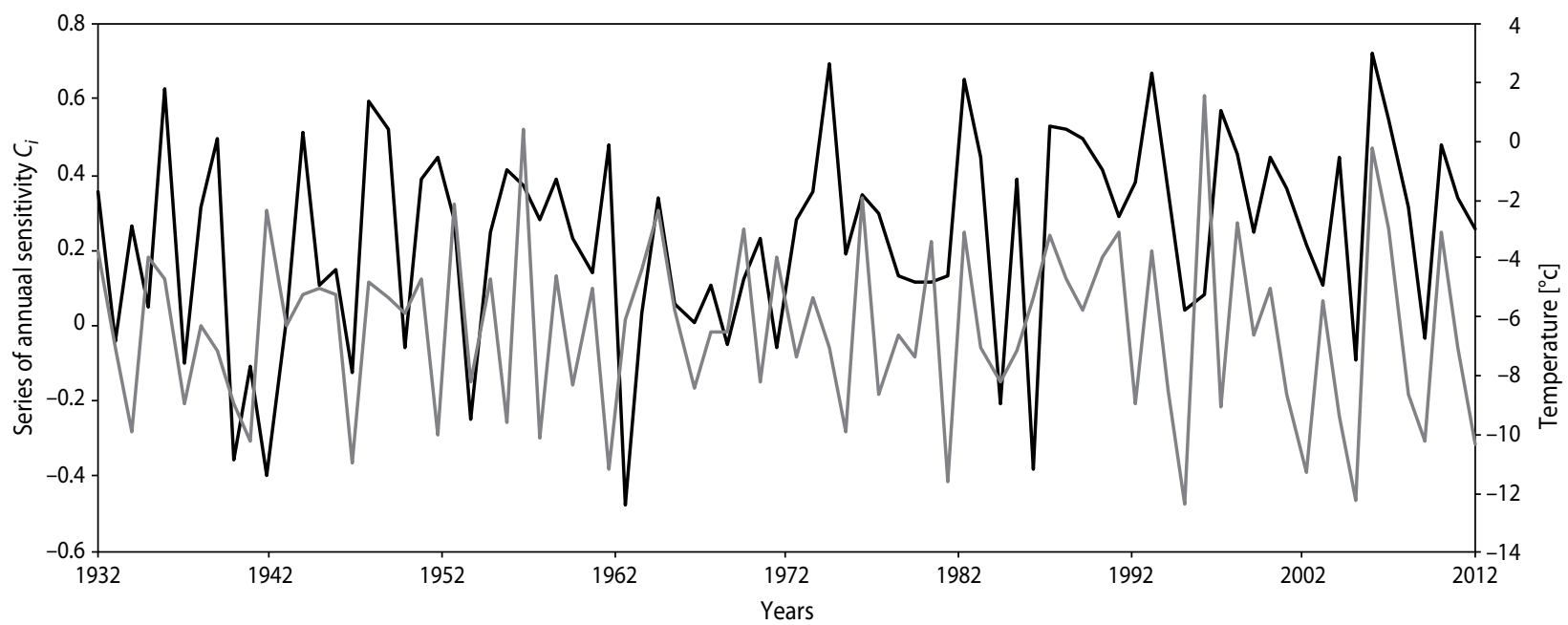

Figure 8. The variation of mean values of $C_{i}$ sensitivity chronology (grey lines) and mean monthly air temperatures of January (black lines) for the period 1932-2013 


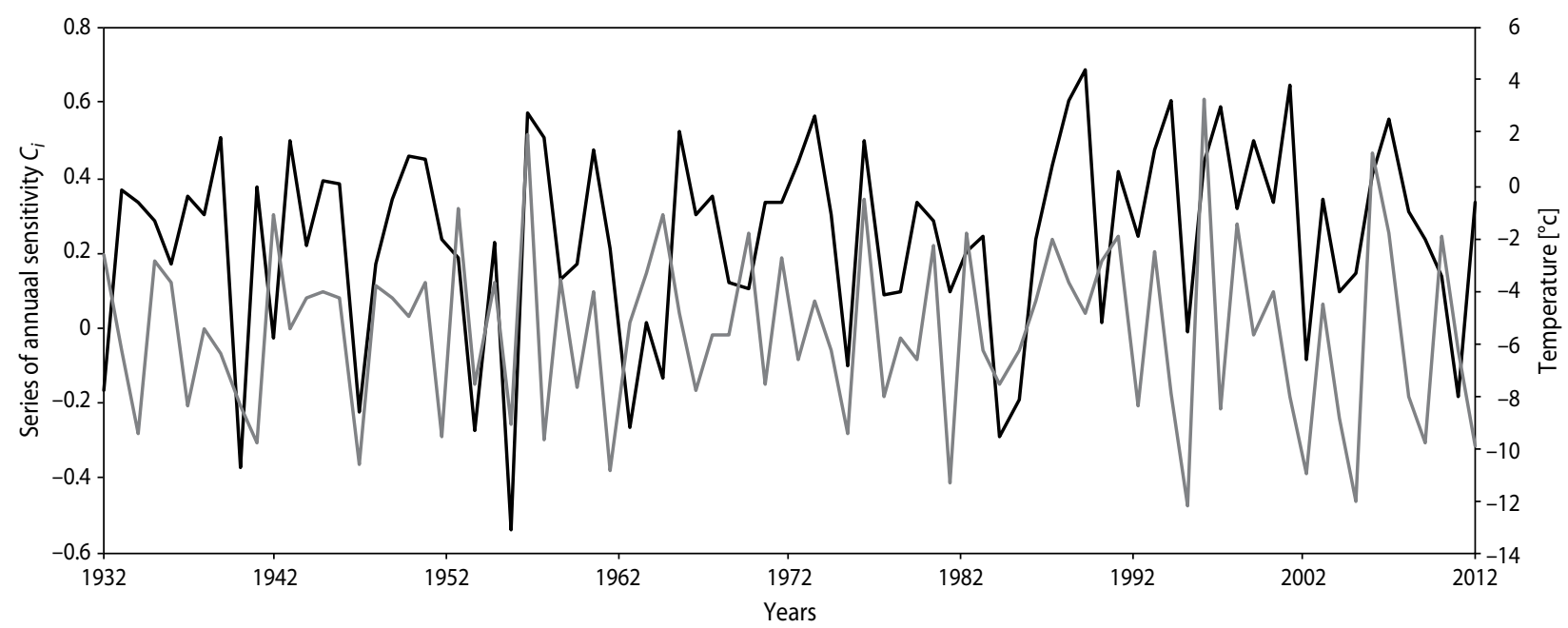

Figure 9. The variation of mean values of $C_{i}$ sensitivity chronology (grey lines) and monthly mean air temperatures of February (black lines) for the period 1932-2013

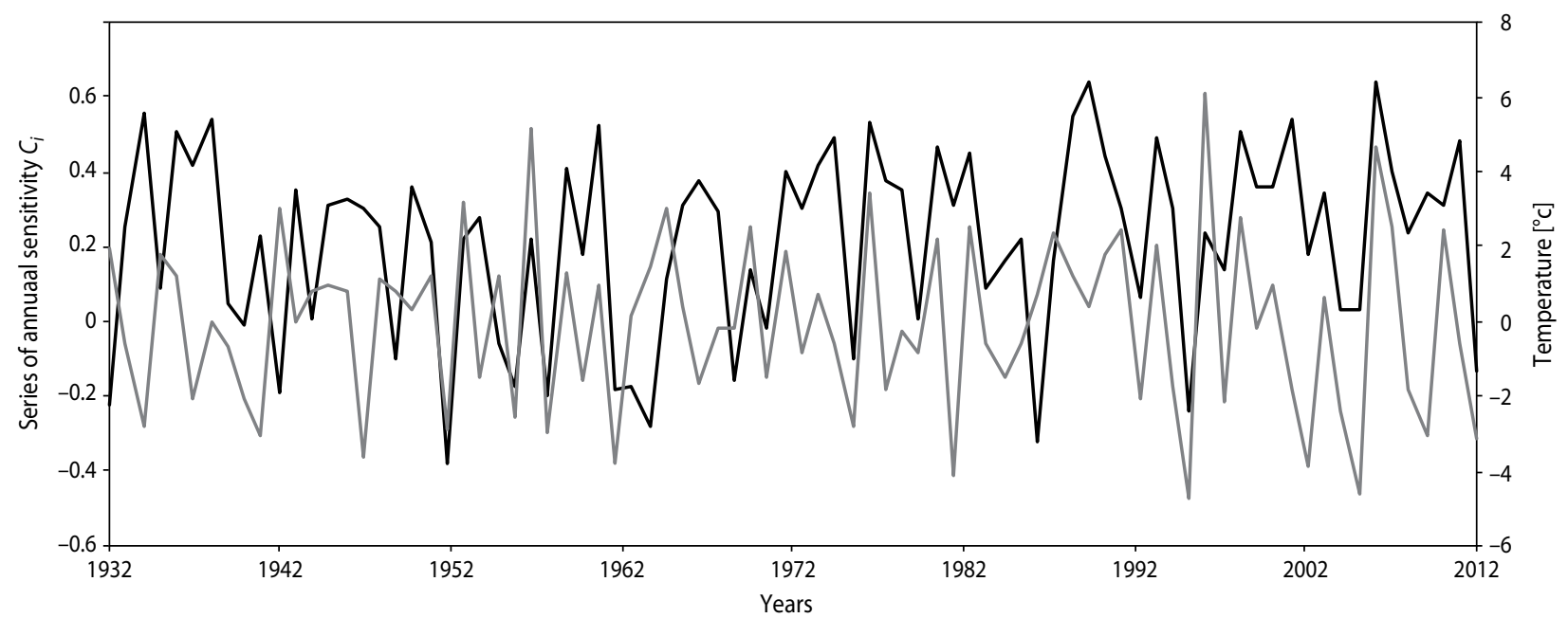

Figure 10. The variation of mean values of $C_{i}$ sensitivity chronology (grey lines) and monthly mean air temperatures of March (black lines) for the period 1932-2013

cold period of early spring determines the incremental response in trees.

A meaningful relationship between precipitation and conditions existing in the warm part of the year was observed. The period from May to June turned out to be significant in this respect (Fig. 6). Precipitation in June shows a clear relationship with annual growth of trees on the plot under examination.

Average values of annual sensitivity $C_{i}$ do not correspond so obviously to precipitation as they do in the case of temperature. However, it seems that the warm part of the year determines the quality of fir growth against a background of recently observed deficiencies of atmospheric humidity in the majority of our country (Fig. 11).

\section{Discussion}

Silver fir belongs to the species susceptible to changing climatic conditions (Jaworski and Zarzycki 1983). In addition, it is considered to be one of the trees with very high humidity requirements, despite the fact that it is marked by relatively low transpiration (Puchalski and 


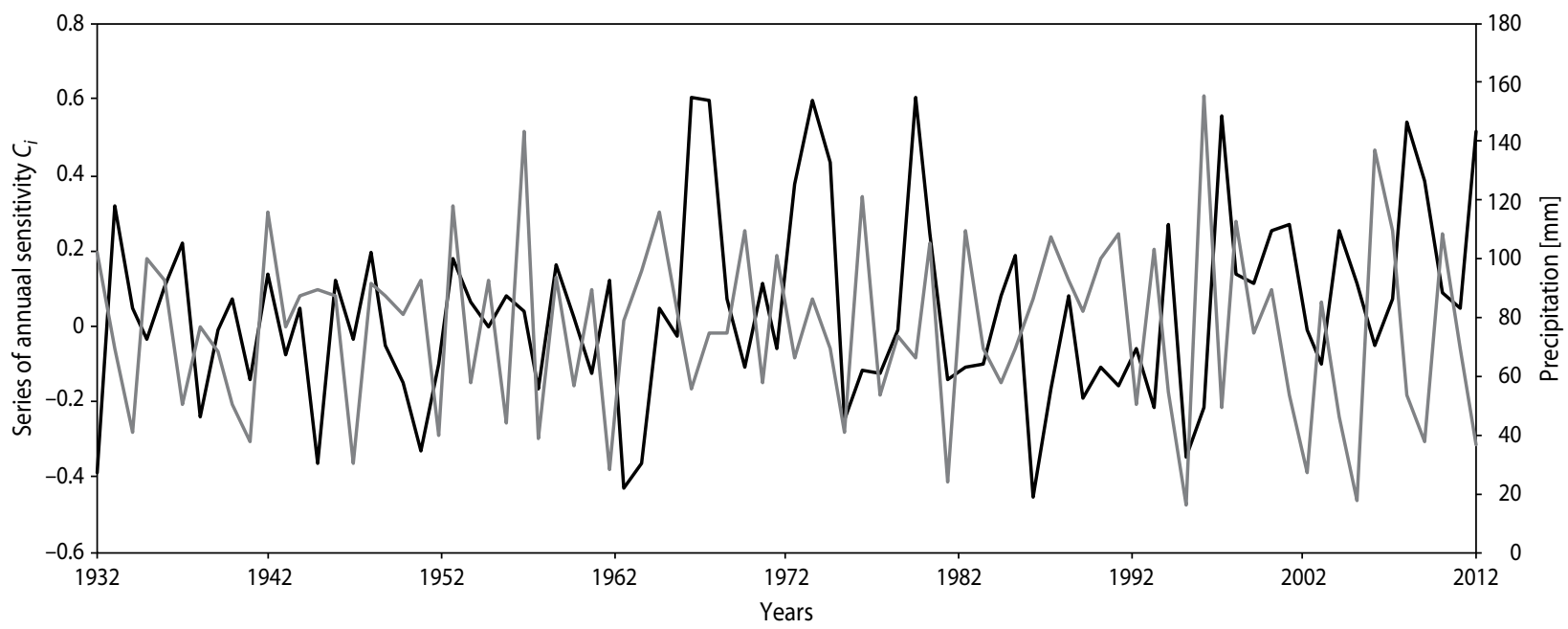

Figure 11. The variation of mean values of $C_{i}$ sensitivity chronology (grey lines) and mean monthly precipitation (black lines) for the period 1932-2013

Prusinkiewicz 1975). For this reason, many researchers consider fir to be a species that prefers habitats rich in moisture. Although, as Bronisz et al. (2010) point out, fir is somewhat capricious, and its behaviour is sometimes unusual, especially in forest habitats.

The research shows that the main factor influencing the increase in the annual growth was the temperature of the end of winter and early spring. Feliksik (1990) drew attention to the dominant role of temperature in that period in shaping the Abies alba growth - believing that the low temperature in winter caused the formation of narrow wood rings in firs. Similar observations can be found by Wilczyński (2010, 2013). Conclusions inferred by authors are reflected in the results presented in this paper, as it turns out that high temperature in December of the preceding year and March of the current year positively influenced the increase in fir ring growth. The relatively high temperature at the beginning of the growing season makes it possible for biochemical and physiological processes to start earlier, which allows the rings to become wider in the following months (Wilczyński and Wertz 2012; Wilczyński 2013). Koprowski and Gławenda (2007) and also confirm the effect of warm winter on the formation of wide rings in firs.

In the case of the analysed trees, precipitation does not show such a significant influence on growth as does the air temperature. No significant correlation was found between the growth in the population of firs and the amount of precipitation in March. Such a situation may be a result of, inter alia, orography of the area, microhabitat relationships, snow cover exposure or duration. Similar doubts are voiced by Bronisz et al. 2010 in a study on fir from the Świętokrzyskie Mountains. They draw attention to the unusual behaviour of fir in relation to precipitation during the warm part of the year. Lebourgeois et al. (2014) showed that temperature played a more important role than precipitation in the radial growth of $A$. alba and Fagus sylvatica L. growing in the western European mountains. Carrer et al. (2010) showed a strong correlation between precipitation and radial growth in different Mediterranean forests. In addition, it should be noted that the amount of precipitation from May to July shows a significant impact on the completion of formation of earlywood layers and the start of formation of latewood layers (Wilczyński 2013). April and May in mountain areas is a period of development of young shoots and leaves in fir (Feliksik 1990). It is during this time that fir is exposed to damage caused by late slight frost, such as damage to the assimilation apparatus or inhibition of cambium activity. It is worth stressing that monthly climatic values used to characterise indicator years are not a sufficiently precise measure of interaction between the weather conditions and the value of tree-ring growth. This is mainly due to the fact that, for example, ground frost or severe frost, occurring locally and for a short period of time, makes it difficult to identify them among the monthly indicators. 
The analysis made it possible to verify and, what is most important, to deepen the knowledge on the ecology of fir, which is extremely important for forest management in the context of the recent changes taking place in the low-forest zone in the mountains of southern Poland. Disintegration of fir stands and redevelopment of stands at the climatic zone, which takes place in many regions, result in the growing importance of fir; therefore, foresters rightly state that an increase in its percentage up to 2.5-3.0\% may be beneficial for the environment in the long run. For example, Lebourgeois et al. (2013) found that $A$. alba showed less growth depression during summer drought when growing in a mixture with $F$. sylvati$c a$ on dry, but not on mesic and humid sites.

The obtained values of EPS and SNR indicate the presence of the strong climatic signal and confirm the high representativeness of the research material; however, it is undoubtedly necessary to broaden the scope of research in order to verify all the results. This is also supported by the fact that there are no other documented reports on the relationship between climate and tree-ring growth from the Carpathian Foothills (Podkarpackie) region for this species. The area under study is located in the natural range of fir occurrence in Poland. Given the high economic quality of the tree stand under study, it can be assumed that this area creates favourable conditions for growth of the species, despite fresh coniferous forest predominates as a habitat type, covering $32.4 \%$ of total area (PUL 2012). The main species dominant in this area is the Scots pine (Pinus sylvestris L.), which occupies $82.2 \%$ of the area, therefore, when planning future sylvicultural treatments for the presented species in this region of the Carpathian Foothills, it is worth recalling the results obtained by Jaworski and Zarzycki (1983), Dobrowolska (1999), Ambroży (2002), who stated that pine stand has a beneficial effect on the initiation and growth of fir regeneration. The above results refer to mountain areas, but in the future, they may contribute to an increase in the percentage of this species also in lowland areas in favourable habitat and orographic conditions.

\section{Conclusions}

1. Fir growing in the Rudnik Forest District is more sensitive to low temperatures in the end of winter and early spring than to the shortage of precipita- tion in the growing season. The main factors that limit its growth are cold winters, cool and low-rainfall summers, and rainy springs.

2. The average temperature of March has the most significant influence on the formation of fir increments.

3. High values of $r_{\text {mean }}$ (0.58), EPS (0.95), SNR (18.2) obtained in this study confirm the very good quality of collected research material and the presence of a strong climatic signal in the rings of population's trees.

4. Fir in the Rudnik Forest District meets favourable growth conditions in this area, even though the majority of the area is dominated by the habitat-type forest, that is, fresh coniferous forest.

5. Future tending and protective measures should be directed towards supporting the already existing fir regenerations. In Rudnik Forest District, fir is a very desirable species, which in the future could contribute to increase the biodiversity of forest ecosystems of this area and Poland's lowlands.

\section{ReferenCes}

Ambroży, S. 2002. Analysis of chosen environmental factors according to the problem of silver fir (Abies alba Mill.) regeneration decline (in Polish). Prace Instytutu Badawczego Leśnictwa., Ser. A, 958, $37-59$.

BDL. 2017. Bank Danych o Lasach. Available at www. bdl.lasy.gov.pl (access on 17 August 2014).

Bernadzki, E. 2008. Jodła pospolita. Państwowe Wydawnictwo Rolnicze i Leśne, Warszawa.

Bijak, S. 2013. Climate signal in the radial growth of selected coniferous species from the Forest Experimental Station in Rogów (in Polish). Leśne Prace Badawcze, 74 (2), 101-110. DOI: 10.2478/frp-20130010

Bronisz, A., Bijak, S., Bronisz, K. 2010. Dendroclimatological characteristics of silver fir (Abies alba Mill.) in the Świętokrzyskie Mountains (in Polish). Sylwan, 154 (7), 463-470.

Carrer, M., Nola, P., Motta, R., Urbinati, C. 2010. Contrasting tree-ring growth to climate responses of Abies alba toward the southern limit of its distribu- 
tion area. Oikos, 119 (9), 1515-1525. DOI: 10.1111/ j.1600-0706.2010.18293

Dobrowolska, D. 1999. Przyszłość jodły pospolitej (Abies alba Mill.) w naszych lasach. In: „Stan i perspektywy badań z zakresu hodowli lasu”. Materiały I Konferencji Leśnej, 18-19 maja 1999, Sękocin Las, Instytut Badawczy Leśnictwa, Warszawa, 179-185.

Eckstein, D., Bauch, J. 1969. Beitrag zur Rationalisierung eines dendrochronologischen Verfahrens und zur Analyse seiner Aussagesicherheit. Forstwissenschaftliches Centralblatt, 88, 1, 230-250. DOI: 10.1007/BF02741777

Feliksik, E. 1990. Badania dendroklimatologiczne dotyczące jodły (Abies alba Mill.) występującej na terenie Polski. Zeszyty Naukowe Akademii Rolniczej im. Hugona Kotłataja w Krakowie, 151.

Fritts, H.C. 1976. Tree-rings and climate. Acad. Press, New York.

Holmes, R.L. 1986. Quality control of crossdating and measuring a user manual for program Cofecha. In: Tree-rings chronologies of western North America: California, eastern Oregon and northern Great Basin (eds.: R.L. Holmes, R.K. Adams, H.C. Fritts). Chronology Series 6. Univ. of Arizona, Tucson, 41-49.

Huber, B. 1943. Über die Sicherheit jahresringchronologischer Datierung. Holz als Roh- und Werkstoff, 6, 10/12, 263-268. DOI: 10.1007/BF02603303

Jaworski, A. 2011. Charakterystyka hodowlana drzew leśnych. Państwowe Wydawnictwo Rolnicze i Leśne, Warszawa.

Jaworski, A., Zarzycki, K. 1983. Ekologia. In: Jodła pospolita Abies alba Mill. Nasze Drzewa Leśne (ed.: S. Białobok). Państwowe Wydawnictwo Rolnicze i Leśne, Warszawa-Poznań, 317-430.

Kondracki, J. 2011. Geografia regionalna Polski. Państwowe Wydawnictwo Naukowe, Warszawa.

Koprowski, M., Gławenda, M. 2007. Dendrochronological analysis of silver fir (Abies alba Mill.) annual increments in the Olsztyńskie Lakeland (Wichrowo Forest District) (in Polish). Sylwan, 151 (11), 35-40. Lebourgeois, F., Gomez N., Pinto P., Merian, P. 2013. Mixed stands reduce Abies alba tree-ring sensitivity to summer drought in the Vosges mountains, western Europe. Forest Ecology and Management, 303, 61-71. DOI: 10.1016/j.foreco.2013.04.003
Lebourgeois, F., Eberlé, P., Mérian, P., Seynave, I. 2014. Social status-mediated tree-ring responses to climate of Abies alba and Fagus sylvatica shift in importance with increasing stand basal area. Forest Ecology and Management, 328, 209-2018. DOI: 10.1016/j.foreco.2014.05.038

Puchalski, S., Prusinkiewicz, Z. 1975. Ekologiczne podstawy siedliskoznawstwa leśnego. Państwowe Wydawnictwo Rolnicze i Leśne, Warszawa.

PUL. 2012. Forest management plan for Rudnik Forest District, 2012-2021 (in Polish). Biuro Urządzania Lasu i Geodezji Leśnej, Lublin.

Roczniki Meteorologiczne IMGW. 1932-2012.

StatSoft. Inc. 2011. Statistica 10. Available at: www. statsoft.com.

Sugiero, D. 2005. Common fir (Abies alba Mill.) in stands of the complex of the fertile Carpathian beech (Dentario glandulosae-Fagetum) (in Polish). Sylwan, 149 (11), 42-49.

Szymura, T. 2008. The changes of vitality, size and age structure of silver fir populations on the north boundary of its range in Western Poland (in Polish). Studia Naturae, 54 (2), 185-198.

Tomanek, J. 1996. Botanika leśna. Państwowe Wydawnictwo Rolnicze i Leśne, Warszawa.

Trampler, T., Kliczkowska, A., Dmyterko, E., Sierpińska, A. 1990. Regionalizacja przyrodniczo-leśna na podstawach ekologiczno-fizyczno-geograficznych. Państwowe Wydawnictwo Rolnicze i Leśne, Warszawa.

Ukleja-Dobrowolska, D. 1989. The fir decline - still an unexplained phenomenon (in Polish). Sylwan, 133 (6), 59-65.

Wigley, T.M.L., Briffa, K.R., Jones, P.D. 1984. On the average value of correlated time series, with applications in dendroclimatology and hydrometeorology. Journal of Climate and Applied Meteorology, 23, 201-213.

Wilczyński, S. 2004. Specyficzność regionów górskich. In: Dendrochronologia (eds.: A. Zielski, M. Krąpiec). Państwowe Wydawnictwo Naukowe, Warszawa, 267-268.

Wilczyński, S. 2010. Determinants of radial growth in some tree species on Kielecka Upland in light of dendroclimatological analyses (in Polish). Zeszyty Naukowe Uniwersytetu Rolniczego im. Hugona Kollątaja w Krakowie. Rozprawy, 464 (341), 1-221. 
Wilczyński, S. 2013. Short-term incremental response of silver fir, Norway spruce and Scots pine growing in uniform habitat conditions (in Polish). Sylwan, 157 (6), 442-452.

Wilczyński, S., Wertz, B. 2012. Sygnał klimatyczny w seriach przyrostów radialnych jodły pospolitej oraz modrzewia europejskiego. Studia i Materiaty CEPL w Rogowie, 1 (30), 66-74.

Zawada, J. 1978. Growth-related symptoms of fir regression on the basis of studied in selected stands (in Polish). Sylwan, 122 (12), 7-16.

Zawada, J. 1987. Growth characterization of health condition of fir forests in Poland. In: II Krajowe
Sympozjum nt. „Reakcje biologiczne drzew na zanieczyszczenia przemysłowe”. 16-19 maja 1984, Kórnik. Wydawnictwo Naukowe Uniwersytetu im. Adama Mickiewicza w Poznaniu, 423-427.

Zawada, J. 2001. Incremental symptoms in revitalization of silver fir in the forests of Carpathian and Sudeten Mts. and the silcultural consequences (in Polish). Prace Instytutu Badawczego Leśnictwa, Ser. A, 922, 79-101.

Zielski, A., Krąpiec, M. 2009. Dendrochronologia. Państwowe Wydawnictwo Naukowe, Warszawa. 